\title{
OBOZOWISKO LOWIECKIE LUDNOŚCI KULTURY ŚWIDERSKIEJ NA STANOWISKU SULEJÓWEK 4, POW. MIŃSKI, WOJ. MAZOWIECKIE
}

\section{SWIDERIAN CULTURE HUNTING CAMP AT THE SITE 4 IN SULEJÓWEK, MAZOVIAN VOIVODESHIP}

\author{
Michat Przeździecki \\ https://orcid.org/0000-0002-8605-3941 \\ Wydział Archeologii, Uniwersytet Warszawski \\ ul. Krakowskie Przedmieście 26/28, 00-927 Warszawa \\ m.przezdziecki@uw.edu.pl
}

\begin{abstract}
The paper presents results of an analysis of the assemblage of flint artefacts from the site no. 6 in Sulejówek, Mazovian Voivodeship. The main attention was focused on technological and typological observations. Based on the obtained results, these materials were interpreted as a remnant of a medium-sized hunting camp of the Swiderian community. An important feature of the inventory is the extremely high proportion of relics made of chocolate flint, which was imported from about $150 \mathrm{~km}$.
\end{abstract}

KEY WORDS: Late Palaeolithic, Tanged Points Complex, Swiderian culture, lithic analyses, raw materials

Celem artykułu jest prezentacja wyników analizy zabytków krzemiennych pozyskanych w 2019 r. podczas badań wykopaliskowych na stanowisku 4 w Sulejówku, pow. miński, woj. mazowieckie ${ }^{1}$. Badanie te miały charakter ratowniczy i były związane z budową drogi ekspresowej S17 Warszawa-Garwolin, odcinek węzeł „Zakręt” - węzeł „Lubelska”. Należy podkreślić, że do odkrycia stanowiska doszło

\footnotetext{
${ }^{1}$ Autor pragnie podziękować dr hab. Pawłowi Szymańskiemu oraz dr Annie Juga-Szymańskiej odkrywcom stanowiska; firmie „Asinus” Igor Maciszewski za udostępnienie materiałów i możliwość ich opracowania; Pawłowi Dziechciarzowi oraz Aleksandrze Pałasz, którzy wykonali część rycin; Dr. Witoldowi Grużdziowi za szereg cennych uwag do niniejszego tekstu.
} 
już w trakcie realizacji inwestycji, kiedy to podczas nadzoru archeologicznego na odsłoniętej przez spychacz powierzchni wykopu budowlanego zarejestrowano skupisko zabytków krzemiennych. Niestety w wyniku odhumusowywania doszło do jego częściowego zniszczenia, tj. zniwelowania partii stropowej i silnego rozwleczenia w płaszczyźnie horyzontalnej.

Mimo znacznego stopnia degradacji stanowiska, przeprowadzone badania ratownicze dostarczyły wartościowego i ciekawego zespołu znalezisk, umożliwiających sformułowanie szeregu wniosków na temat genezy, funkcji oraz klasyfikacji kulturowo-chronologicznej odkrytej koncentracji.

\section{POLOŻENIE STANOWISKA, UWARUNKOWANIA GEOLOGICZNE I STRATYGRAFIA}

Z perspektywy podziału fizycznogeograficznego omawiane stanowisko położone jest przy południowo-zachodnim skraju Równiny Wołomińskiej (ryc. 1: A), w strefie bezpośredniego pogranicza trzech innych mezoregionów - Doliny Środkowej Wisły, Kotliny Warszawskiej oraz Równiny Garwolińskiej, przy czym wszystkie one wchodzą w skład Niziny Mazowieckiej (Kondracki, 2002, s. 188, 193-196; Solon i in., 2018; Korpak, 2020). Z kolei z perspektywy studiów osadniczych lokalizacja stanowiska Sulejówek 4 pokrywa się z zasięgiem kompleksu stanowisk schyłkowopaleolitycznych, odkrywanych od początku XX w. (Sawicki, 1933-1936, s. 1-23; Krukowski, 1939-1948, s. 82-87; Schild, 1975, s. 267-270; Schild, 2014, s. 19-22) zarówno na obszarze tarasów nadzalewowych (praskiego, falenickiego, otwockiego), jak i w strefie wysoczyznowej, m.in. wzdłuż zachodniej krawędź Równiny Wołomińskiej (Bogdański, 1990).

Równina Wołomińska to denudacyjno-erozyjna wysoczyzna morenowa tworzona głównie przez gliny zwałowe, żwiry i piaski zlodowacenia Warty, interglacjalne iły wstęgowe, lokalnie zaś przez osady powstałe podczas zlodowacenia Wisły, w tym piaski eoliczne (Kapera i in., 2009, s. 6-14). W obrębie jednej z takich „piaszczystych łach", przykrywających relatywnie cienką warstwą (ok. 40-60 cm) polodowcowe gliny morenowe, zlokalizowane jest stanowisko Sulejówek 4.

Analiza topograficzna obszaru stanowiska - w chwili rozpoczęcia badań już całkowicie przekształconego przez budowę drogi - wskazuje, że miejsce odkrycia znalezisk pokrywa się z granicami niewielkiej wyniosłości, związanej z rozległym kompleksem wydm położonym ok. $250 \mathrm{~m}$ na północ (ryc. 1: B). Zabytki rejestrowane były wyłącznie w warstwie jednorodnego, jasnożółtego piasku (warstwa 2) o miąższości ok. 20-30 cm, zalegającego na warstwie gliny wyznaczającej calec archeologiczny (warstwa 3). Z kolei powyżej warstwy 2 wydzielona została warstwa 1, miąższości ok. $25-35 \mathrm{~cm}$, obejmująca poziom próchniczny oraz słabo czytelny poziom wymywania współczesnej gleby bielicowej. 


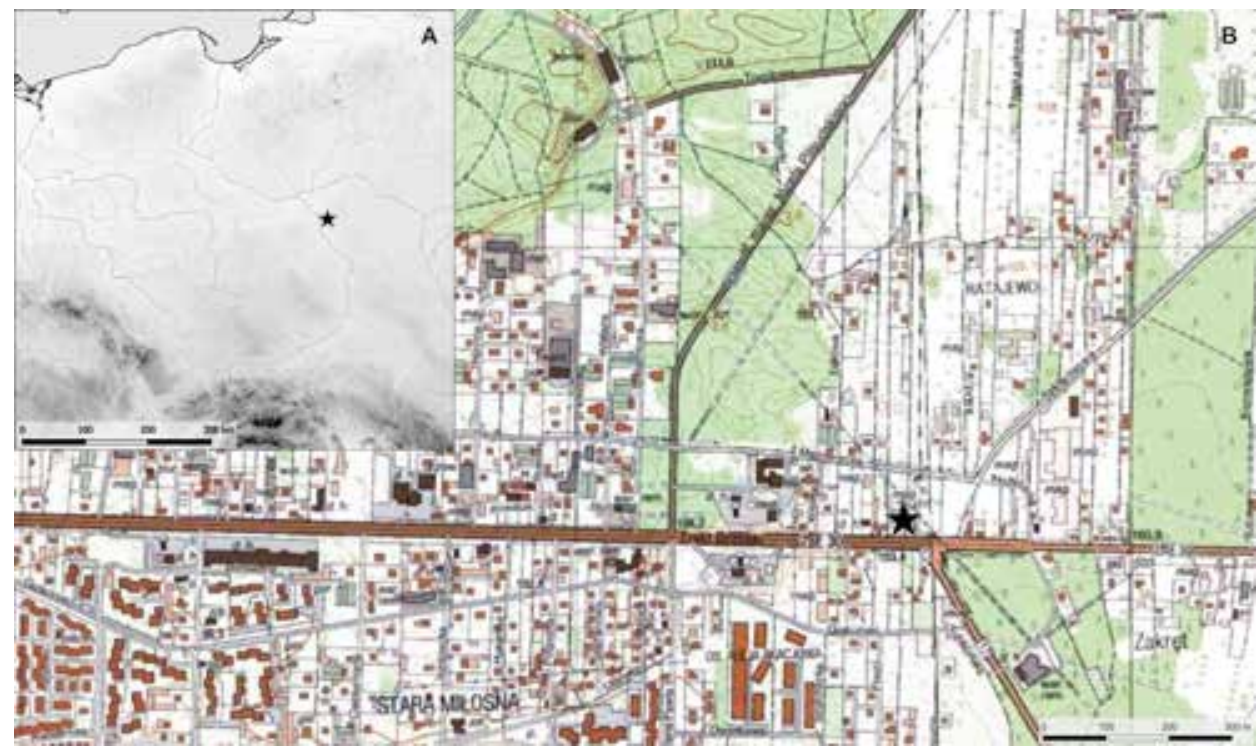

Ryc. 1. Lokalizacja stanowiska Sulejówek 4, województwo mazowieckie (rys. P. Dziechciarz)

Fig. 1. Localization of site 4 in Sulejówek, masovian voivodeship (drawing by P. Dziechciarz)

\section{METODYKA BADAŃ}

Z racji na okoliczności odkrycia stanowiska w procesie jego rozpoznania wyróżnić możemy dwa odrębne etapy badawcze, tj.:

- prospekcji powierzchniowej obejmującej stosunkowo rozległy obszar w okolicy ujawnionego podczas nadzoru skupiska zabytków;

- stacjonarnych badań wykopaliskowych obejmujących swym zasięgiem główną koncentrację znalezisk (krzemienice I, II) oraz niewielki buforowy obszar w ich bezpośrednim sąsiedztwie (ryc. 2).

Wspomniane formy badań znajdują bezpośrednie odzwierciedlenie w liczebności, strukturze, a przede wszystkim w sposobie dokumentacji pozyskanych materiałów. W pierwszym przypadku były one lokalizowane $\mathrm{z}$ dokładnością od kilku do kilkunastu metrów w ramach trzech odrębnych skupisk (A, B, C). Inną cechą zbioru powierzchniowego jest zdecydowana przewaga znalezisk o stosunkowo dużych rozmiarach. Z odwrotną sytuacją mamy do czynienia w kontekście inwentarza z badań wykopaliskowych, gdzie dominują drobne łuski i okruchy (średnicy poniżej $5 \mathrm{~mm}$ ). Poza tym zabytki pozyskane podczas wykopalisk posiadają dokumentację umożliwiającą precyzyjne określenie ich położenia oraz kontekstu występowania.

Eksplorację prowadzono poziomami mechanicznymi o miąższość od 5 do $10 \mathrm{~cm}$, a wszystkie zabytki rejestrowane w trakcie odczyszczania poszczególnych poziomów domierzano trójwymiarowo i nanoszono na plan zbiorczy konkretnego metra. Ponadto 
cała „luźna ziemia” z wykopu została przesiana na sitach o średnicy oczka $2 \mathrm{~mm}$. W ten sposób udało się pozyskać liczną grupę drobnych artefaktów - łusek, okruchów. Z oczywistych względów nie mają punktowych koordynatów, a jedynie ogólną lokalizację, $\mathrm{z}$ dokładnością do konkretnego metra kwadratowego oraz poziomu mechanicznego.

Efektem przyjętej metodyki jest nie tylko bogaty, ale przede wszystkim kompletny, a tym samym w pełni reprezentatywny zespół znalezisk, obudowany pakietem danych przestrzennych.

\section{KONTEKST WYSTĘPOWANIA I ROZPRZESTRZENIENIE ZNALEZISK}

Wszystkie zabytki krzemienne wystąpiły w obrębie relatywnie cienkiej warstwy $\mathrm{nr} 2$. Z uwagi na to, że jeszcze przed rozpoczęciem badań stanowisko zostało w znacznym stopniu zniszczone przez usunięcie nadległej warstwy nr 1, wszelkie uwagi dotyczące pozycji stratygraficznej oraz wertykalnej dyspersji znalezisk muszą zostać ograniczone do stwierdzenia, że wystąpiły one w rozproszonym grawitacyjnie układzie, w spągu niewielkiej wydmy podściełanej przez warstwę glin czwartorzędowych - warstwa nr 3.

Równie enigmatyczne wnioski dotyczą rozrzutu horyzontalnego znalezisk, choć w tym przypadku wydzielić możemy dwie, wprawdzie mocno zniszczone, ale wyraźne koncentracje (ryc. 2), odpowiadające skupiskom A i B zarejestrowanym podczas badań powierzchniowych ${ }^{2}$. Charakteryzowały się one podobnymi rozmiarami oraz zbliżonym, tj. niezbyt regularnym elipsoidalnym kształtem, wydłużonym na osi północ-południe. Pierwsze z nich oznaczone jako krzemienica I, o szerokości ok. 5,5-6,5 m i długości ok. $13 \mathrm{~m}$, zarejestrowana została w zachodniej części arów 38 oraz 48. W jej obrębie pozyskano łącznie 253 artefakty krzemienne, w tym większość zarejestrowanych na stanowisku produktów modyfikacji debitażu, tj. narzędzi oraz odpadków z ich produkcji. Około 3,5 m na wschód od krzemienicy I, w granicach arów 37 i 38, zlokalizowane było drugie skupisko (krzemienica II) o długości ok. $18 \mathrm{~m}$ i szerokości ok. $3 \mathrm{~m}$, przy czym jego główną oś wyznaczał wąski pas znalezisk o szerokości ok. 1,5 m. Podczas jego eksploracji natrafiono na 270 zabytków, należy przy tym podkreślić, że nie było wśród nich ani jednej formy narzędziowej.

Bez wątpienia zadokumentowany układ oraz kształt skupisk należy interpretować jako efekt zniszczeń powstałych podczas niwelacji terenu przez ciężki sprzęt budowlany. W wyniku tego procesu doszło do rozwleczenia opisywanych koncentracji pierwotnie zdecydowanie mniejszych, bardziej zwartych wewnętrznie i wyraźnie od siebie odizolowanych. Z kolei występowanie narzędzi w krzemienicy I, przy jednoczesnej absencji tego typu form w obrębie krzemienicy II, sugeruje odmienną funkcję tych skupisk.

\footnotetext{
${ }^{2}$ Skupisko C, położone w zachodniej części stanowiska, w którego skład wchodziły zaledwie trzy zabytki, zostało w całości „wyeksplorowane” jeszcze na etapie prospekcji powierzchniowej.
} 


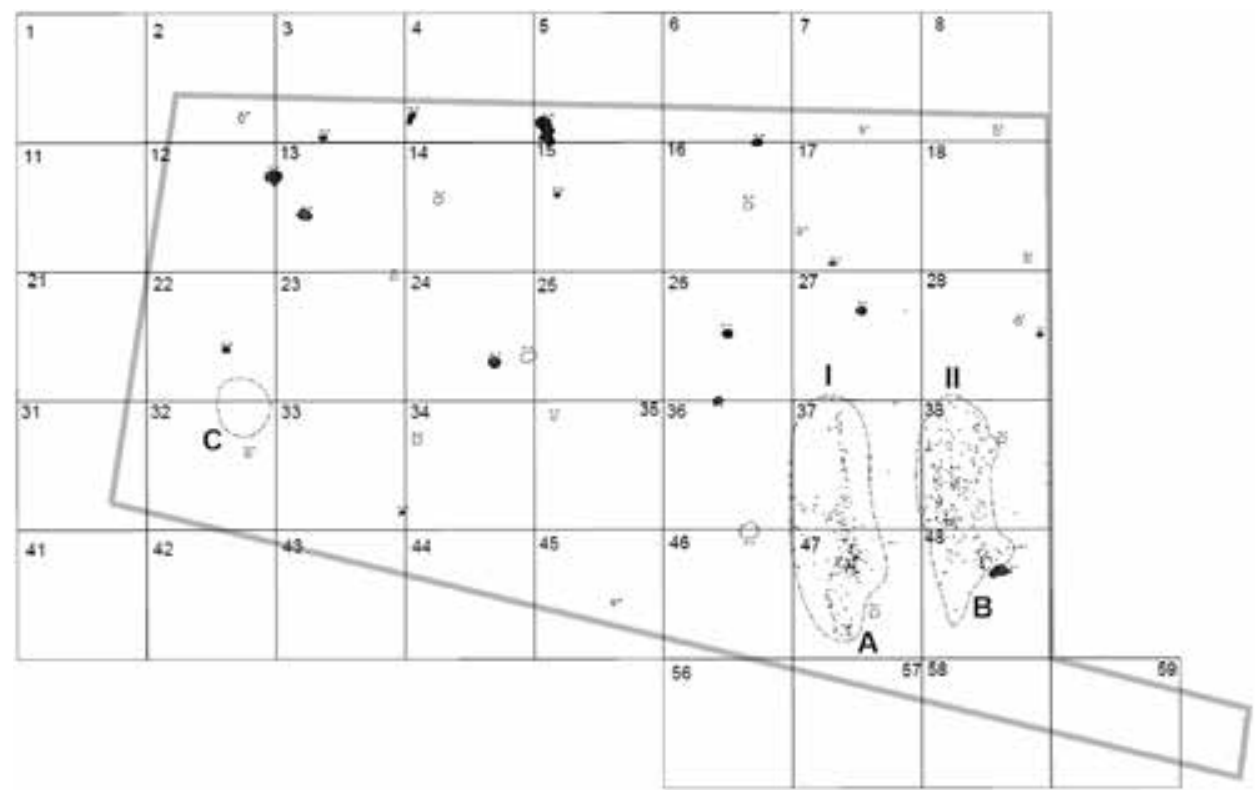

Ryc. 2. Stanowisko Sulejówek 4. Plan zbiorczy wykopu archeologicznego - dyspersja zabytków krzemiennych (punkty) i obiektów nowożytnych (plamy). Zaznaczono koncentracje artefaktów krzemiennych - krzemienice I i II (przerywana linia) (rys. I. Maciszewski)

Fig. 2. Sulejówek site 4. Collective plan of the archaeological excavation - dispersion of the flint artefacts (dots) and modern objects (stains). The scattered flint are marked - concentrations I and II (dashed line) (drawing by I. Maciszewski)

\section{ANALIZA}

\section{Struktura surowcowa i stan zachowania}

Na stanowisku zarejestrowano łącznie 593 artefakty krzemienne, z czego 58 okazów pozyskano podczas prospekcji powierzchniowej, tj. w trybie nadzorów, zaś pozostałych 535 zbytków podczas ratowniczych badań wykopaliskowych.

Z wyjątkiem dwóch znalezisk, do produkcji których użyto narzutowego krzemienia bałtyckiego, a także fragmentu wióra $\mathrm{z}$ krzemienia świeciechowskiego, pozostała część inwentarza wykonana jest z krzemienia czekoladowego. Występuje on w trzech odmianach, różniących się pod względem barwy, stopnia przeźroczystości oraz tekstury (plamistością, obecnością wtrętów lub pasmowania). Stwierdzona na powierzchni kilku okazów gruba warstwa dobrze zachowanej, pozbawionej śladów erozji kory świadczy, że surowiec ten pozyskiwano bezpośrednio ze złóż. $Z$ powodu wciąż nierozstrzygniętej dyskusji dotyczącej z jednej strony podstaw klasyfikacji krzemieni czekoladowych, $\mathrm{z}$ drugiej zaś metod dokładnego określania ich proweniencji, na obecnym etapie badań możemy stwierdzić jedynie, że surowiec występujący 
na stanowisku pochodzi z szeroko pojętej strefy północnego przedpola Gór Świętokrzyskich (Budziszewski, 2008), przy czym jego najbliższe złoża znajdują się na lewym brzegu Wisły w okolicach Orońska, ok. $100 \mathrm{~km}$ na południe od granicy Równiny Wołomińskiej (Schild, 1971).

Przykładem jeszcze odleglejszego importu jest fragment wióra z krzemienia świeciechowskiego, występującego ok. $150 \mathrm{~km}$ na południowy zachód od stanowiska. Warto zwrócić uwagę, że w przeciwieństwie do surowca czekoladowego wychodnie krzemienia szarego biało nakrapianego zlokalizowane są na prawym brzegu Wisły (Libera, Zakościelna, 2002).

Surowce lokalne $\mathrm{w}$ inwentarzu reprezentowane są zaledwie przez dwa zabytki - półtylczak typu Komornica oraz zatępiec - obydwa wykonane z krzemienia narzutowego bałtyckiego. Krzemień ten stanowi naturalny komponent występujących w okolicy Sulejówka osadów czwartorzędowych (głównie glin lub żwirów wodolodowcowych), przy czym zazwyczaj rejestrowany jest w postaci drobnych, spękanych bryłek o średnicy nieprzekraczającej $6 \mathrm{~cm}$.

Omawiając stan zachowania znalezisk, należy podkreślić wysoką frekwencję zabytków przekształconych termicznie. Ślady mniej lub bardziej wyraźnych zmian cieplnych stwierdzono w przypadku niemal $60 \%$ okazów, przy czym w ich obrębie możliwe było wydzielenie trzech grup odzwierciedlających różne stopnie przekształceń termogenicznych:

- egzemplarze słabo przepalone, noszące ślady dyskretnych zmian (zazwyczaj o charakterze strefowym), przejawiające się lekkim zaczerwienieniem powierzchni;

- egzemplarze średnio przepalone, charakteryzujące się wyraźnym zaczerwienieniem powierzchni oraz obecnością poligonalnej siatki spękań;

- egzemplarze silnie przepalone, których najważniejszą cechą jest zamiana pierwotnej barwy surowca na brunatną, czarną lub szarą. Dodatkowymi elementami są: wyraźna sieć spękań, liczne odpryski oraz silna fragmentaryzacja.

Innym ważnym atrybutem znalezisk krzemiennych odkrytych na stanowisku jest brak patyny, w tym tzw. patyny eolicznej (wyświeceń powierzchni, zagładzeń grani międzynegatywowych), która kojarzona jest z długotrwałą ekspozycją zabytków na warunki zewnętrzne. Obserwacja ta może wskazywać, że omawiany zbiór stosunkowo szybko został przykryty osadem i zalegał w jego obrębie przez większość czasu.

Omawiając stan zachowania znalezisk, należy także zwrócić uwagę na wysoki stopień ich rozdrobnienia/fragmentacji, spowodowany oddziaływaniem czynników termicznych (okruchy - 12\% zbioru) lub mechanicznych (fragmenty - $31 \%$ zbioru), przy czym najwięcej okazów niekompletnych wystąpiło w grupie wiórów. Silne zróżnicowanie pod względem rozmiarów, proporcji oraz cech morfologicznych (części: proksymalne, medialne lub dystalne), sugeruje przypadkową genezę złamań - związanych z etapem produkcji bądź postdepozycji. 


\section{Struktura techno-morfologiczna zbioru}

Na najbardziej ogólnym poziomie w analizowanym zespole wydzielić możemy trzy, główne kategorie wytworów (ryc. 3):

- produkty debitażu, w skład których wchodzą wióry i wiórki - 207 szt., odłupki - 109 szt., łuski - 176 szt. oraz rdzeń - 1 szt. (ryc. 4);

- produkty modyfikacji, obejmujące narzędzia typologiczne (formy retuszowane) - 19 szt. wraz z charakterystycznymi odpadkami z ich produkcji lub napraw -6 szt. oraz tzw. narzędzia funkcjonalne 5 szt. (ryc. 6);

- destrukty, tj. różnego typu okruchy i ułamki nieprzemysłowe, np. termo- lub kriogeniczne -70 szt. (ryc. 3 ).

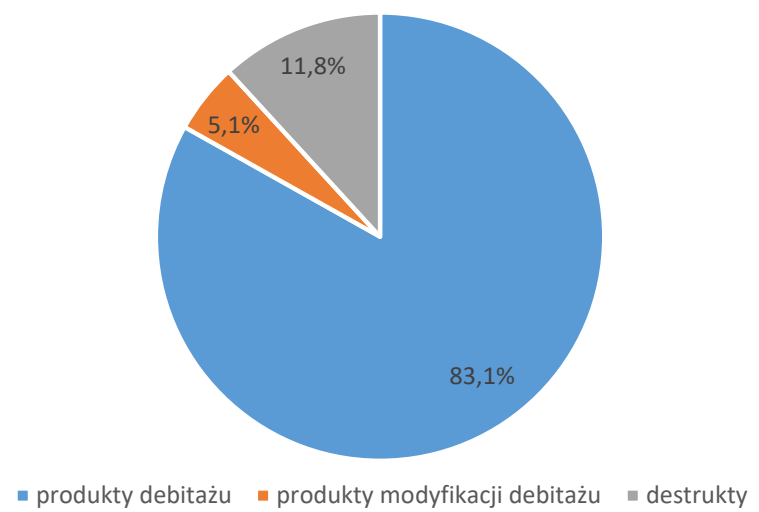

Ryc. 3. Stanowisko Sulejówek 4. Frekwencja głównych kategorii techno-typologicznych (rys. M. Przeździecki)

Fig. 3. Sulejówek site 4. Percentages of the main techno-typological categories (drawing by M. Przeździecki)

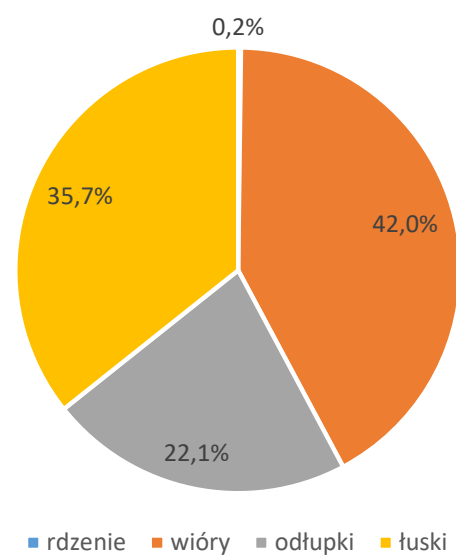

Ryc. 4. Stanowisko Sulejówek 4. Frekwencja produktów debitażu (rys. M. Przeździecki)

Fig. 4. Sulejówek site 4. Percentages of the debitage products (drawing by M. Przeździecki) 


\section{CHARAKTERYSTYKA PRODUKTÓW DEBITAŻU}

Do tej kategorii zaliczono łącznie 493 wytwory, przy czym zasadniczy rys badanego inwentarza wyraża się $\mathrm{w}$ dominacji bardzo regularnych wiórów dwupiętowych, pochodzących z zaawansowanych faz eksploatacji rdzenia (ryc. 5: 1). Przeważają okazy o symetrycznym przebiegu krawędzi bocznych, prostym profilu, uporządkowanym reliefie negatywów na stronie górnej, niewielki piętkach oraz prawidłowo, tj. łagodnie wyklinowanych wierzchołkach - zarejestrowano zaledwie trzy formy o zakończeniach zawiasowych - ang. hinge lub step termination i jedną formę przeniesioną - ang. plunging termination (Andrefsky, 2005, s. 20, 21).

Odrębną kategorię tworzy seria wiórów technicznych - czterech zatępców i dziewięciu podtępców, a także kilkunastu form podkorowych. Do grupy dystynktywnych form o charakterze technicznym należy zaliczyć także serię wiórów lub wiórków korekcyjnych (Dziewanowski, 2006, 2011), w tym ang. upsilon blades (Wilke, Qintero, 1994; Qintero, Wilke, 1995) (ryc. 9: 2).

Kolejne miejsce wśród produktów debitażu zajmują odłupki, które są prawie dwukrotnie mniej liczne od wiórów. Gros z nich stanowią okazy bezkorowe - zarejestrowano zaledwie cztery egzemplarze w pełni pokryte korą oraz dziewięć podkorowych. Charakteryzują się przy tym stosunkowo niewielkimi rozmiarami, co zdaje się wskazywać na związek z zabiegami korekcyjnymi podejmowanymi w zaawansowanych fazach eksploatacji. Niestety bardziej szczegółowa identyfikacja kontekstu technologicznego możliwa była zaledwie w przypadku trzech fragmentarycznie zachowanych odnawiaków oraz kilku drobnych zatępiaków. W przeciwieństwie do wiórów większość odłupków charakteryzuje się relatywnie dużymi płaszczyznowymi piętkami o soczewkowatym lub esowatym zarysie, ponadto mniej intensywny i rzadszy jest zabieg prawcowania ich krawędzi.

Odrębną grupę tworzy 176 bardzo drobnych form o średnicy poniżej $1 \mathrm{~cm}$, określonych jako łuski. Zaliczono tu zarówno wytwory o proporcjach wiórowych, jak i odłupkowych, często zachowane jedynie fragmentarycznie. $Z$ powodu niedystynktywnego technologicznie charakteru tych form, o trudnej do odtworzenia roli w procesie eksploatacyjnym, w niniejszym tekście zrezygnowano z ich szczegółowej analizy.

Opis produktów debitażu zamyka wykonany z krzemienia czekoladowego regularny rdzeń wiórowy o płytkowatej formie i wymiarach 62/32/21 mm (ryc. 5: 2). Do jego najważniejszych atrybutów należy obecność dwóch naprzeciwległych pięt tworzących z odłupią kąt ok. 45 stopni. Pięta górna ma charakter płaszczyznowy i jest dobrze wyodrębniona, $z$ kolei pięta dolna stanowi w zasadzie fragment tyłu, a jej powierzchnia w części pokryta korą - sprawia wrażenie przygotowanej doraźnie. Opisane różnice morfologiczne odzwierciedlają nie tylko inny sposób przygotowania pięt, ale także ich odmienną funkcję. Uwaga ta znajduje bezpośrednie odzwierciedlenie m.in. w parametrach odłupni, która charakteryzuje się obecnością długich i regularnych negatywów wiórowych, przy czym wszystkie z nich oddzielone zostały od pięty górnej. Jedynym świadectwem odbić wyprowadzonych do strony pięty dolnej są dwa niewielkie nega- 
tywy o proporcjach odłupkowych lub wióroodłupkowych, stanowiące ślad zabiegów korekcyjnych, związanych z zabiegiem izolacji wierzchołka wiórów preferencyjnych (Dziewanowski, 2011). Mimo że opisywany rdzeń to forma silnie zredukowana (wyzyskana), charakteryzuje się jednak dużym stopniem regularności, w tym brakiem negatywów zawiasowych typu hinge czy przeniesionych typu plunging.

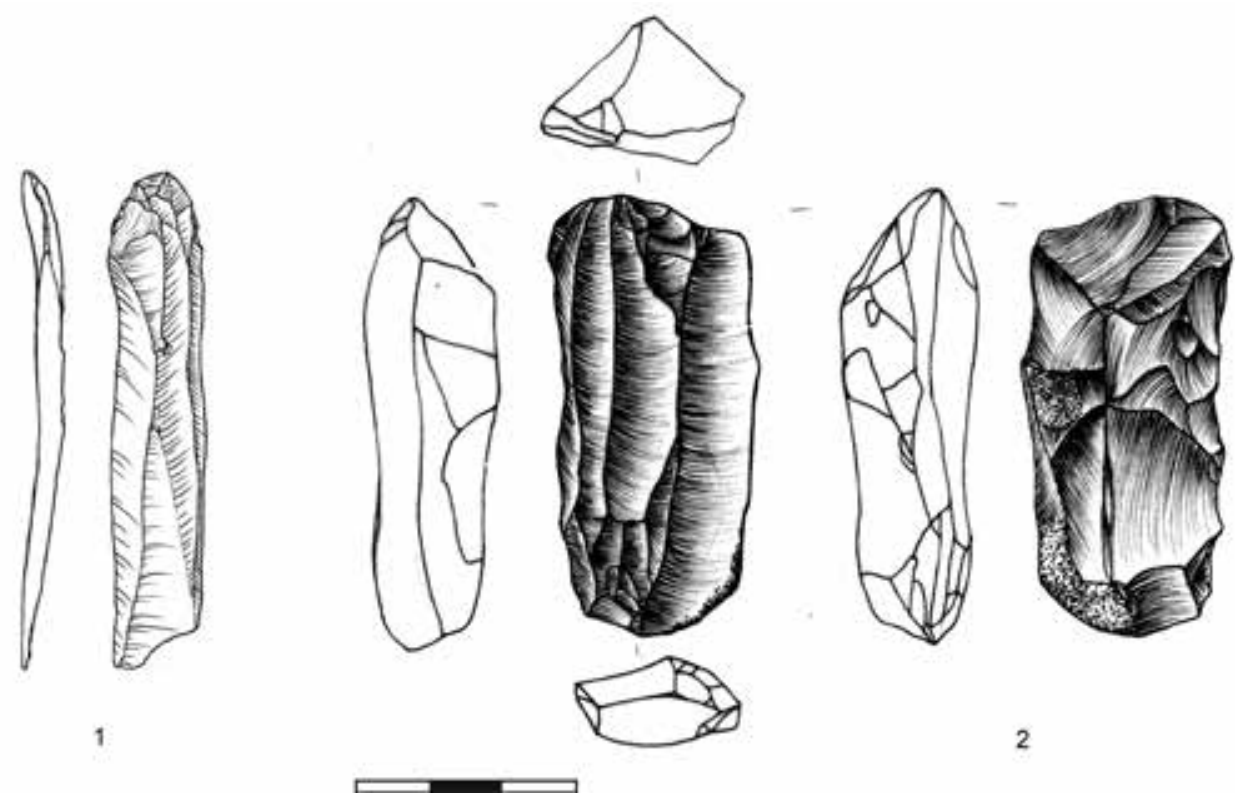

Ryc. 5. Stanowisko Sulejówek 4. wiór predeterminujący - 1; rdzeń dwupietowy - 2 (rys. A. Pałasz)

Fig. 5. Sulejówek site 4. Predetermined blade - 1; double platform core Percentages of the debitage products (drawing by A. Pałasz)

\section{CHARAKTERYSTYKA FORM NARZĘDZIOWYCH}

Na stanowisku zarejestrowano relatywnie dużą liczbę 24 narzędzi lub ich fragmentów, przy czym poza formami retuszowanymi w tym zestawie znalazło się pięć tzw. narzędzi funkcjonalnych. $Z$ wyjątkiem pojedynczego okazu zostały one wykonane z krzemienia czekoladowego. Najbardziej charakterystyczną, a zarazem najliczniejszą grupę stanowi siedem liściaków (ryc. 7: 1-7, ryc. 9: A, 10), w tym trzy formy silnie uszkodzone, $\mathrm{z}$ powodu stanu zachowania $\mathrm{w}$ dalszych częściach analizy określane jako potencjalne liściaki (ryc. 7: 2, 6, 7). Kolejne miejsca zajmują cztery drapacze (ryc. 7: 8-11) oraz trzy rylce (ryc. 7: 12, ryc. 8: 6). Listę narzędzi zamykają dwie formy określone jako wióry retuszowane (ryc. 8: 2, 3), fragment przekłuwacza uformowanego na dystalny końcu wióra lub odłupka, proksymalny fragment nieokreślonego (pękniętego wzdłużnie) narzędzia wiórowego lub odłupkowego z wyraźnym, stromym retuszem krawędzi i podstawy oraz mikrolitycz- 
ny półtylczak typu Komornica, wykonany z krzemienia narzutowego bałtyckiego (ryc. 8: 4).

Jak już wyżej wspomniano, do grupy narzędzi zaliczono także serię wiórów z mniej lub bardziej wyrazistymi negatywami, tzw. retuszu funkcjonalnego (ryc. 8: 1,5$)$, w postaci krótkoodcinkowych - pojedynczych lub zwielokrotnionych skupień rozproszonych wzdłuż jednej lub obu krawędzi. Choć ich lokalizacja oraz intensywność mają zasadniczo charakter przypadkowy, to jednak należy zwrócić uwagę na to, że niemal we wszystkich przypadkach retusz ten obejmuje ok. 5-10 mm fragment krawędzi w części proksymalnej wióra, w miejscu jej załamania, na styku z płaszczyzną piętki. Poza negatywami retuszu na krawędziach omawianych form, występują także liczne wyszczerbienia. Do szczególnie ciekawych okazów należy smukły, relatywnie duży wiór dwupiętowy o wymiarach 73/23/5,5 mm z widocznymi na dwóch krawędziach śladami odcinkowych retuszy użytkowych (ryc. 8: 1).

Należy podkreślić, że zaproponowana powyżej interpretacja śladów oparta jest wyłącznie na obserwacjach cech makroskopowych i wymaga potwierdzenia za pomocą specjalistycznych badań traseologicznych. Do czasu ich przeprowadzenia klasyfikacja tych form jako narzędzi może mieć wyłącznie charakter hipotetyczny.
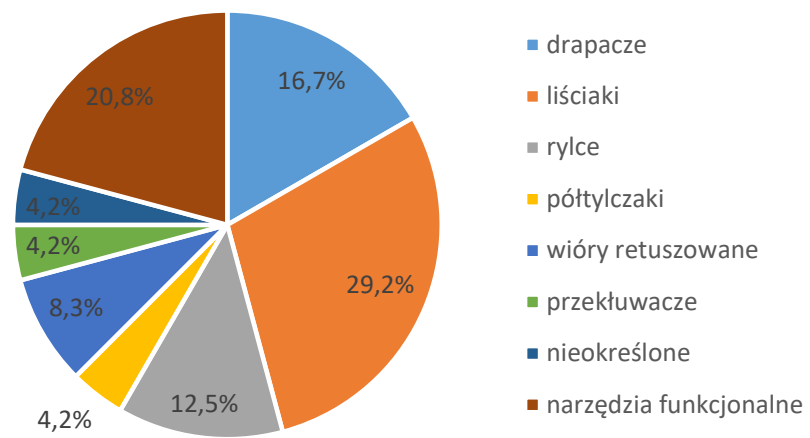

Ryc. 6. Stanowisko Sulejówek 4. Frekwencja poszczególnych typów form retuszowanych (narzędzi) (rys. M. Przeździecki)

Fig. 6. Sulejówek site 4. Percentages of the retouched forms (flinty tools) (drawing by M. Przeździecki)

Ze względu na szereg specyficznych cech, kluczowych w ocenie homogeniczności oraz klasyfikacji kulturowo-chronologicznej analizowanego zbioru, poniżej przedstawiono szczegółowy opis najbardziej charakterystycznych okazów.

- Bardzo smukły liściak, średnich rozmiarów (59/10,5/3,5 mm), z wyodrębnionym trzonkiem retuszowanym płasko na stronę spodnią, ale bez śladów retuszu na stronę wierzchnią (ryc. 7: 1). Trzpień zakończony drobnym negatywem wskazującym na przypadkowe złamanie lub celowy zabieg związany z procesem formowania trzonka (kontrolowanym odłamywaniem części przy- 
piętkowej wióra). Pod względem cech formalnych (retusz na stronę spodnią) nawiązuje on do ostrzy typu Hintersee ${ }^{3}$.

- Silnie zdegradowany termicznie fragment liściaka o wymiarach 54/17/6 mm ze śladami szczątkowego retuszu dwóch krawędzi w partii proksymalnej (ryc. 7: 2, 9: 1$)^{4}$. Niestety wysoce niekompletny stan zachowania okazu (mimo wykonanej składanki dwóch elementów) uniemożliwia zarówno jego szczegółowy opis, jak i dokładną atrybucję typologiczną. Niewątpliwie była to forma duża, o długości co najmniej 65-75 mm, wykonana na regularnym wiórze dwupiętowym o prostym profilu, klinowatym przekroju podłużnym i wrzecionowatym zarysie. Poza rodzajem oraz umiejscowieniem retuszu argumentem przemawiającym za przyjętą klasyfikacją funkcjonalną wydaje się występowanie w partii proksymalnej okazu pseudo-negatywu o charakterze zawiasowym, który można by interpretować jako ślad impaktu (Fischer, 1989).

- Zachowany niemal w całości (ułamany wierzchołek) liściak typu Świdry (ryc. 7: 3). Forma bardzo regularna (symetryczna), a przy tym wyjątkowo dużych rozmiarów $(76 / 15,5 / 6,5 \mathrm{~mm})$, wykonana na wiórze technicznym (podtępcu), o czym świadczy obecność serii negatywów zorientowanych poprzecznie w stosunku do osi odbicia okazu.

- Uszkodzony termicznie fragment liściaka typu Świdry (brak wierzchołka) średniej wielkości, tj. o wymiarach 47,5/10,5/3 mm (ryc. 7: 4). Okaz wyjątkowo smukły, o bardzo regularnym, wrzecionowatym kształcie. Uwagę zwraca obecność u podstawy trzpienia dwóch drobnych negatywów quasi-rylcowczych, ilustrujących proces celowego odłamywania (kurtyzowania) piętki oraz sęczka wióra.

- Drobny liściak świderski o wymiarach 38/11/4,5 mm (ryc. 7: 5) wykonany na wiórze korekcyjnym. Efektem adaptacji kształtu ostrza do formy półsurowca jest asymetryczne położenie wierzchołka oraz trzonka, tj. na przedłużeniu jednej z krawędzi. Interesującym elementem jest obecność płaskawego retuszu na stronę spodnią, obejmującego środkowy odcinek „wypukłej” krawędzi liściaka.

- Potencjalny proksymalny fragment liściaka nieokreślonego typu o wymiarach 33/15/2,5 mm z wyraźnym, półstromym retuszem dwóch krawędzi na stronę górną (ryc. 7: 6). Charakterystyczną cechą jest zachowany sęczek oraz piętka. Umiejscowienie i sposób wykonania retuszu pozwalają klasyfikować ten okaz na trzy sposoby, tj. jako fragment formy skończonej - trzonek ostrza typu Lyngby lub jako fragment półwytworu - niedokończony liściak typu świderskiego, który podczas produkcji uległ złamaniu. Trzecia, alternatywna interpretacja zakłada, że de facto nie mamy do czynienia z ostrzem (grotem strzały), a narzędziem o zupełnie innej, bliżej nieokreślonej funkcji.

\footnotetext{
${ }^{3}$ Klasyfikacja liścików wg. Taute, 1968, s. 10-13, ryc. 1.

${ }^{4}$ Na ryc. 7: 2 przedstawiono omawiany liściak w postaci pojedynczego elementu (niezłożonej), a na rycinie 9: $1 \mathrm{w}$ formie składanki.
} 
- Niewielki proksymalny fragment potencjalnego liściaka (18/13/3 mm) z wyraźnym półpłaskim retuszem na stronę górną zlokalizowanym na jednej krawędzi oraz drobnym łuskaniem (retuszem użytkowym) na drugiej krawędzi okazu (ryc. 7: 7). Obydwie krawędzie zbiegają się, tworząc ostre zakończenie, dodatkowo podkreślone obecnością negatywu po impakcie. W przypadku rozważań na temat szczegółowej atrybucji typologicznej mamy do czynienia z opcjami analogicznymi, jak w przypadku egzemplarza opisanego wyżej.

- Fragment drapacza o wymiarach 40/14/5 mm wykonanego na dwupiętowym wiórze podkorowym (ryc. 7: 8). Słabo wyodrębnione drapisko umiejscowione jest dosyć nietypowo, bo w partii proksymalnej okazu. Wzdłuż jednej z krawędzi widoczne są drobne negatywy i wyszczerbienia związane, jak się wydaje, z procesem użytkowania narzędzia.

- Drapacz wiórowy z lekko ukośnym drapiskiem zlokalizowanym w części proksymalnej. Do specyficznych cech należy także płaskawe łuskanie na stronę spodnią okazu jednej z krawędzi, przy czym szczególnie intensywne jest ono w partii dystalnej (ryc. 7: 9), ponadto na obu krawędziach okazu występują ślady pseudoretuszu użytkowego. Zidentyfikowane atrybuty sugerują wielofunkcjonalny charakter opisywanego narzędzia.

- Silnie przepalony fragment drapacza wiórowego o wymiarach 30/14/5 mm (ryc. 7: 10). Okaz wykonany na dwupiętowym, doborowym wiórze, z drapiskiem uformowanym w części proksymalnej półsurowiaka.

- Fragment drapacza na regularnym wiórze dwupiętowym o wymiarach 38,5/17,5/4 mm (ryc. 7: 10). Lekko zakolone, symetryczne drapisko - podobnie jak w przypadku wcześniej opisanych egzemplarzy - zlokalizowane jest w partii proksymalnej okazu. Cechą analogiczną jest również występowanie retuszu funkcjonalnego wzdłuż krawędzi bocznych drapacza.

- Potencjalny fragment rylca, wykonany na submakrolitycznym wiórze dwupiętowym $(118 / 31 / 10 \mathrm{~mm})$, o relatywnie małej, płaskiej piętce, słabo wysklepionym sęczku, za to opatrzonym wyraźną wargą (ryc. 8: 6). Wątpliwości co do klasyfikacji typologicznej okazu wynikają z tego, że pozbawiony jest on fragmentu części pracującej/wierzchołkowej, która uległa złamaniu. $\mathrm{Z}$ drugiej jednak strony dwa negatywy identyfikowane jako świadectwa odbić rylcowych wydają się ewidentne. Poza rozmiarami cechą wyróżniającą analizowany egzemplarz jest obecność intensywnego, płaskawego retuszu na stronę wierzchnią, zlokalizowanego w proksymalnej partii wióra. Ponadto na niemal całej długości krawędzi występują ślady użytkowania w postaci wyszczerbień oraz mikronegatywów, z kolei w okolicach części przysęczkowej zarejestrowano wyraźne, dostrzegalne makroskopowo wyświecenia.

- Medialny fragment (46,5/15,5/5 $\mathrm{mm})$ regularnego wióra dwupiętowego z odcinkowym zwrotnym retuszem dwóch krawędzi (ryc. 8: 2).

- Dystalny fragment wióra dwupiętowego o wymiarach 36/19/9 z wyraźnym, płaskawym retuszem jednej krawędzi na stronę wierzchnią (ryc. 8: 3). 

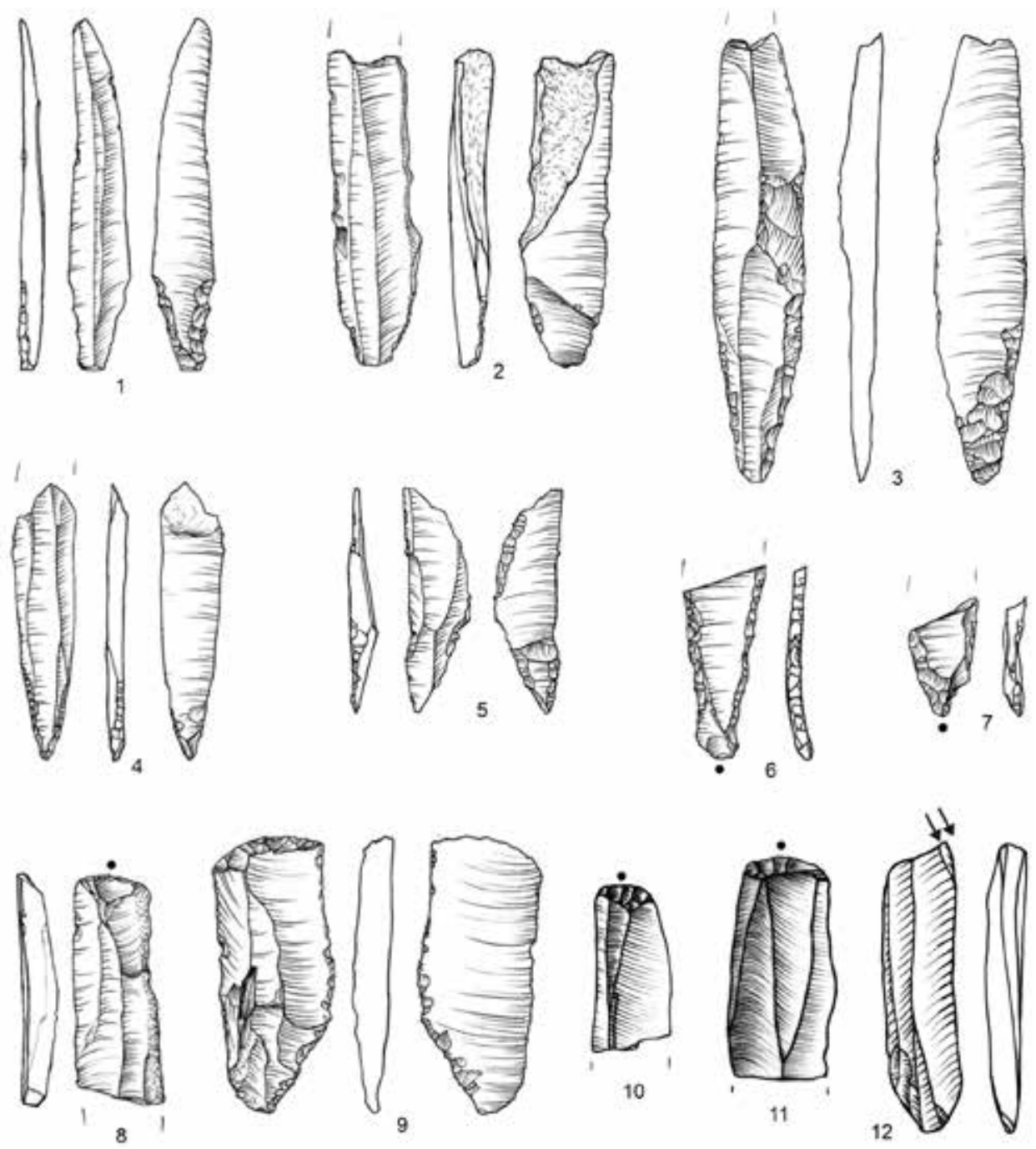

Ryc. 7. Stanowisko Sulejówek 4. Wybrane przykłady form narzędziowych. Liściaki - 1-7; drapacze $8-11$; rylec - 12 (rys. A. Pałasz i A. Borowska)

Fig. 7. Sulejówek site 4. Selected examples of flint tools. Tanged points $-1-7$; Endscrapers $-8-11$; burin -12 (drawing by A. Pałasz and A. Borowska) 

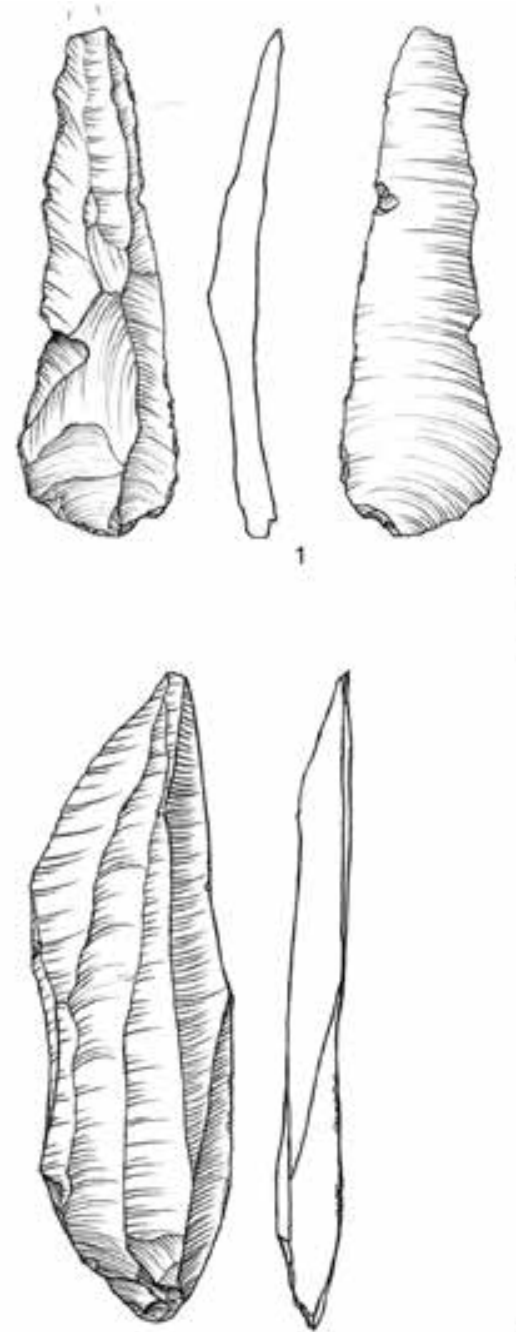

5
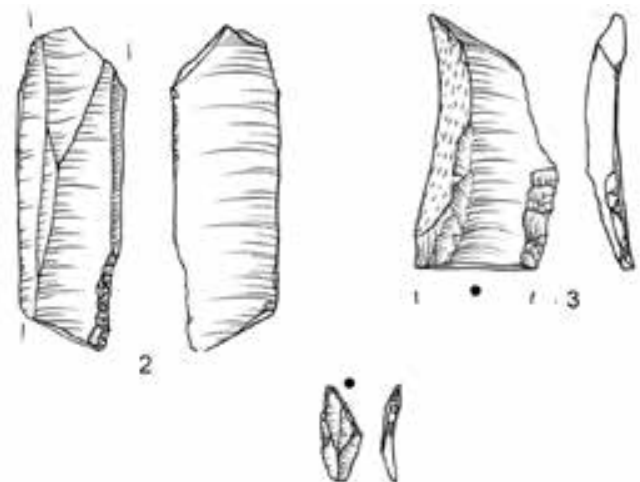

4
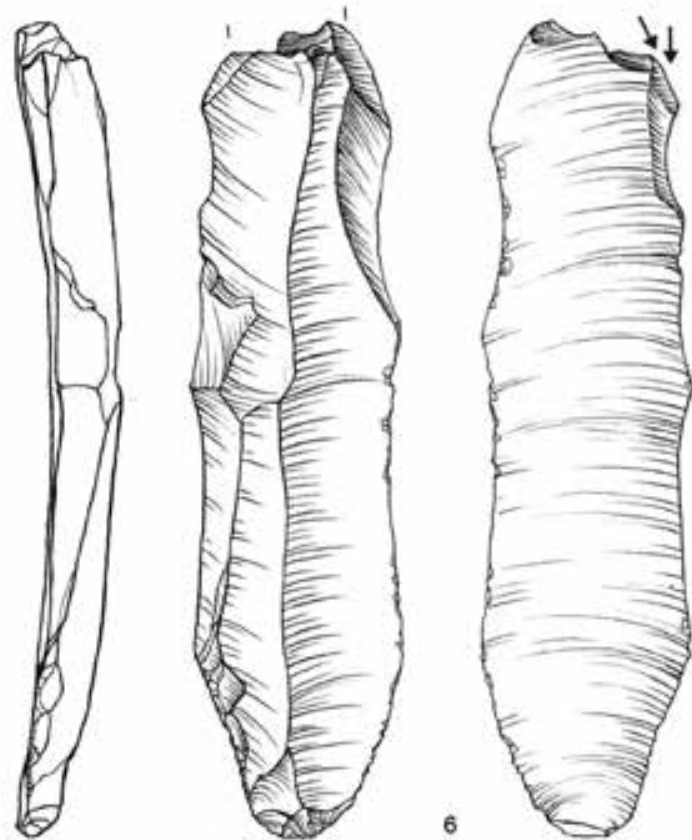

Ryc. 8. Stanowisko Sulejówek 4. Wybrane przykłady form narzędziowych. Wióry ze śladami retuszu funkcjonalnego $-1,5$; wióry retuszowane $-2,3$; zbrojnik mikrolityczny -4 ; rylec -6 .

Fig. 8. Sulejówek site 4. Selected examples of flint tools. Blades with functional traces $-1,5$; scaled blades $-2,3$; microlith -4 ; burin -6 (drawing by A. Pałasz) 


\section{DYSKUSJA}

\section{Gospodarka surowcowa}

Struktura surowcowa inwentarza w jednoznaczny sposób odzwierciedla preferencje późnopaleolitycznych oraz wczesnomezolitycznych twórców analizowanego inwentarza. Pierwsi do produkcji narzędzi kamiennych wykorzystywali importowany krzemień czekoladowy o tzw. cechach kopalnianych. Przedmioty z tego surowca reprezentują wszystkie kategorie technologiczne i typologiczne, związane zarówno z procesem obróbki rdzenia (wióry, odłupki, łuski z różnych faz eksploatacji), jak i z procesem wytwarzania, użytkowania oraz napraw narzędzi. $Z$ odmienną sytuacją mamy do czynienia w przypadku wióra z krzemienia świeciechowskiego, który na teren obozowiska przyniesiony został najprawdopodobniej jako gotowa forma. Wskazuje na to jednostkowy charakter znaleziska, a ściślej brak innych produktów debitaż (choćby drobnych łusek) potwierdzających, że surowiec ten obrabiany był w granicach stanowiska. Bardziej skomplikowana jest kwestia chronologiczno-kulturowej atrybucji omawianego zabytku, który nie dość, że zachowany fragmentarycznie, to jeszcze należy do form mało charakterystycznych. Warto jednak zwrócić uwagę na to, że pojedyncze wyroby z krzemienia świeciechowskiego na interesującym nas obszarze kojarzone są z penetracją dolnego odcinka Doliny Środkowej Wisły przez społeczności schyłkowopaleolitycznego kręgu kultur z liściakami (Libera, 1998, 2002; Tomaszewski, 2002), zarazem brak jest przesłanek wskazujących na import tego surowca w okresie mezolitu. Ze śladami osadnictwa mezolitycznego należy za to łączyć dwa artefakty wykonane $z$ lokalnego narzutowca.

Warto zwrócić uwagę na to, że przywołane uwagi na temat jakości oraz rozmiarów konkrecji surowca narzutowego wydają kłócić się z mediolitycznymi, a w niektórych przypadkach wręcz submakrolitycznymi parametrami wytworów z krzemienia czekoladowego. Obserwacja ta wydaje się szczególnie istotna w kontekście klasyfikacji chronologicznej zatępca. W przeciwieństwie bowiem do półtylczaka typu Komornica brak cech diagnostycznych utrudnia przypisanie tego zabytku do jednego z dwóch wyróżnionych na stanowisku epizodów osadniczych, tj. do starszego lub środkowego okresu epoki kamienia. Obserwacje surowcowe mogą więc w tym przypadku stanowić kryterium pomocnicze, sugerując związek omawianego zatępca ze śladami osadnictwa mezolitycznego.

\section{Kontekst technologiczny oraz rekonstrukcja proces debitażu}

Podsumowując analizę grupy produktów debitażu, w pierwszej kolejności należy zwrócić uwagę na spójny pod względem technologicznym charakter jego poszczególnych komponentów. Czytelny jest on zawłaszcza w kontekście analizy wiórów, gdzie znajduje odzwierciedlenie, zarówno w obecności dwóch, wzajemnie komplementarnych, kategorii - wiórów predeterminujących oraz predeterminowanych, jak 
i w reprezentowanym przez nie zestawie atrybutów. Do grupy najważniejszych, stale powtarzających się cech zaliczono:

- dwupiętowość,

- prosty profil,

- symetryczny przebieg krawędzi bocznych,

- medio- lub submakrolityczne rozmiary wiórów,

- punktowe, silnie prawcowane piętki,

- niewielkie, słabo wysklepione sęczki z charakterystycznym negatywem po odszczepionej łusce,

- sporadyczne występowanie wargi oraz złamań typu esquillements du bulbe.

O ile cztery pierwsze atrybuty dostarczają informacji o metodzie obróbki, w tym przypadku opartej na koncepcji dwupiętowej, to trzy ostatnie cechy wskazują na rodzaj stosowanej techniki (sposobu aplikacji siły), tj. uderzenia bezpośredniego miękkim tłukiem, najprawdopodobniej wykonanego z „miękkiego" kamienia lub ewentualnie z poroża (Pelegrin, 2000). Niemniej teza o użyciu tłuka organicznego wydaje się słabo uzasadniona (pojedyncze wióry z wargą lub złamaniami esquillements $d u$ bulbe), albowiem nie do końca koresponduje z bardzo małymi rozmiarami piętek o punktowej formie.

Inną ważną cechą omawianego zbioru jest występowanie debitażu pochodzącego niemal wyłącznie z zaawansowanych faz obróbki. Wyjątkowo niska frekwencja odłupków korowych, podkorowych, a także wiórów technicznych wskazuje, że proces zaprawy wstępnej rdzenia (włącznie z fazą ekspozycji/otwierania odłupni) odbywał się poza stanowiskiem. Do obozowiska przynoszono rdzenie już zaprawione, a być może nawet już częściowo wyeksploatowane. Wydaje się, że wytwórczość krzemieniarska na stanowisku ograniczała się do doraźnej - choć opartej na ściśle określonym schemacie - produkcji półsurowca wiórowego oraz związanych z tym procesem niezbędnych napraw rdzenia.

Kolejnym, wartym podkreślenia, atrybutem omawianej kolekcji jest wysoka frekwencja tzw. form doborowych, przy minimalnym udziale okazów nieudanych. W przypadku wiórów wspomniana doborowość wyraża się przede wszystkim w jednostkowej obecności okazów z zakończeniami typu hinge (formy zawiasowe) lub plunging (formy przeniesione). Opisane cechy morfologiczne wiórów w połącznie z relatywnie dużymi rozmiarami, niektórych okazów świadczą o wysokim poziomie umiejętności działających na stanowisku łupacza lub łupaczy (Bodu, 1996). Co ważne, teza ta znajduje odzwierciedlenie także w kontekście analizy rdzenia. Mimo że jest to forma silnie zredukowana, charakteryzuje się jednak dużym stopniem regularności - pierwotny układ oraz funkcja płaszczyzn zasadniczych są zachowane, a ich relacje kątowe optymalne, $z$ kolei relief negatywów na odłupni jest uporządkowany, a one same łagodnie wyklinowane, w pełni odpowiadając uśrednionym parametrom obecnych w inwentarzu wiórów. Świadczy to o wysokim poziomie umiejętności wytwórcy, który do samego końca utrzymał kontrolę nad procesem obróbki, zarówno w wymiarze koncepcyjnym (zaplanowanej sekwencji uderzeń), jak i gestów fizycznych (aplikacji uderzeń). $Z$ tej perspektywy analizowany rdzeń należy interpretować 
jako przykład formy porzuconej nie na skutek popełnionych błędów (np. degradacji odłupni), a z powodu maksymalnego wyeksploatowania konkrecji.

W świetle uwag na temat wysokiej frekwencji oraz „doborowego" charakteru wiórów nasuwa się pytanie, czy tylko niewielka ich część przerobiona została na narzędzia lub nosi potencjalne ślady użytkowania. Zdaniem autora formy te w rzeczywistości stanowią efekt selekcji negatywnej, odzwierciedlając z jednej strony uwarunkowania technologiczne (typowe produkty związane $\mathrm{z}$ koncepcją obróbki stadialnej), z drugiej zaś rygorystyczne oczekiwania co do formy, proporcji oraz rozmiarów półsurowca $^{5}$. $Z$ tej perspektywy definicja wiórów doborowych (udanych) nie jest jednoznaczne z pojęciem form stanowiących zasadniczy cel obróbki.

Większość wiórów obecnych w inwentarzu należy traktować jako formy odpadkowe. Teza ta znajduje potwierdzenie w wynikach analiz technologicznych, wskazujących, że działający na terenie obozowiska łupacze stosowali koncepcję obróbki stadialnej (Bradley, Giria, 1996), ukierunkowanej na produkcję jednostkowych form o ściśle określonych (predeterminowanych) parametrach morfometrycznych. W przypadku omawianego zbioru były to relatywnie duże, $\mathrm{tj}$. medio- lub submakrolityczne wióry o prostym profilu i wrzecionowatym zarysie, przeznaczone do produkcji liściaków (egzemplarze delikatniejsze) lub rylców (egzemplarze masywne). Produkcja tego rodzaju wytworów, określanych mianem ostrzy preferencyjnych (Migal, 2006, 2007) wiązała się z szeregiem zabiegów (ściśle określoną sekwencją odbić), których celem było ukształtowanie na odłupni wykroju planowanego wióra. W efekcie tego procesu poza predeterminowaną formą celową generowany był także zestaw różnego typu wiórów oraz wiórków predeterminujących (Dziewanowski, 2006, 2011). To właśnie ta kategoria wytworów stanowi dominującą grupę produktów debitażu w badanym zespole (ryc. 5: 1, ryc. 9: 2), z kolei pojedyncze formy predeterminowane reprezentowane są wyłącznie w grupie narzędzi. $Z$ wyjątkiem zatępców wymienione $\mathrm{w}$ tym zestawieniu tzw. wióry techniczne należy łączyć z zaawansowanymi etapami eksploatacji rdzenia, a ściślej z systematycznie powtarzanym w trakcie obróbki zabiegiem umożliwiającym:

- zachodzenie/poszerzanie odłupni na boki rdzenia,

- kontrolę jej wypukłości horyzontalnej odłupni (Wąs, 2011).

Teza ta znajduje odzwierciedlenie w specyficznej morfologii wiórów podkorowych, o jednym boku krawędziowym, drugim zaś płaszczyznowym, przyjmującym niejako postać naturalnego, pokrytego korą ,tylca”.

\section{Produkcja i wykorzystanie narzędzi}

Podobnie jak miało to miejsce w przypadku produktów debitażu, jedną z najważniejszych cech zwracającą uwagę w kontekście analizy narzędzi jest ich zasad-

\footnotetext{
${ }^{5}$ Po raz pierwszy analogiczny pogląd, thumaczący fenomen masowej obecności „surowych” wiórów na stanowiskach świderskich, przedstawiony został przez Marcina Dziewanowskiego (2012).
} 
niczo spójny charakter. Z jednej strony znajduje on odbicie w wykorzystaniu wyłącznie regularnych wiórów dwupiętowych z krzemienia czekoladowego, a z drugiej - w stosowaniu specyficznych, opisanych szczegółowo powyżej - zabiegów technologicznych. W przypadku drapaczy jest to nietypowy sposób lokowania drapiska na proksymalnym końcu wióra, a także zabieg kurtyzowania, choć akurat ten atrybut wydaje się być związany raczej z procesem użytkowania narzędzi niż ich produkcji. $Z$ kolei tym, co wyróżnia kolekcję liściaków jest specyficzny sposób formowania trzonka za pomocą zabiegu quasi-rylcowczego, polegającego na kontrolowanym odłamywaniu partii przypiętkowej (ryc. 10). Choć poszczególne okazy różnią się istotnie pod względem rozmiarów, to jednak pod względem formy oraz zdecydowanie smukłych proporcji są zestandaryzowane, co pozwala klasyfikować je jako ostrza dwukątowe typu Świdry (Taute, 1968, s. 10-13, ryc. 1). Należy podkreślić, że ślad stosowanie tego zabiegu zarejestrowano również na trzpieniu okazu łuskanego na stronę spodnią, nawiązującego do typu Hintersee. W przypadku wiórów retuszowanych za dystynktywną cechą neleży uznać regularny, półstromy retusz o wyraźnych, stosunkowo dużych negatywach. Przeważnie zlokalizowany jest on w partii proksymalnej, tuż pod piętką.

Jedyną, ewidentnie obcą formą w tym zestawie, wyróżniającą się pod względem surowcowy, typologicznym, jak i technologicznym jest mikrolityczny półtylczak typu Komornica (rys. 8: 4) stanowiacy późniejszą domieszkę mezolityczną.

Omawiając strukturę form retuszowanych, warto także odnotować wyraźnie zarysowujący się w tej grupie podział na elementy broni (groty strzał) stanowiące odzwierciedlenie aktywności łowieckiej oraz narzędzia codziennego użytku związane $\mathrm{z}$ grupą prac tzw. przydomowych, tradycyjnie wiązanych $\mathrm{z}$ obróbką skór (drapacze, rylce) i tusz zwierzęcych (wióry retuszowane). W odpowiedzi na pytanie, który z wyminionych obszarów działaności miał znaczenie podstawowe, pomocna okazuje się analiza frekwencji oraz stanu zachowania liściaków. Wyjątkowo duża, w stosunku do innych kategorii narzędzi, liczba ostrzy, a także to, że reprezentują one zarówno formy uszkodzone, jak i pozbawione wyraźnych śladów użytkowania, a nawet okazy niedokończone, wskazuje na kompletny łańcuch czynności związanych z wytwarzaniem, naprawą oraz wymianą instrumentarium myśliwskiego. Relatywnie wysoka frekwencja tej grupy znalezisk wskazuje na prawdopodobną funkcję stanowiska, które należy interpretować jako pozostałość średniej wielkości obozowiska związanego $\mathrm{z}$ realizacją aktywności łowieckich, tj. pozyskiwaniem i obróbką tusz zwierzęcych. Spektrum tych działań uzupełniały czynności związane z wytwarzaniem lub naprawą narzędzi, co znajduje potwierdzenie w obecność serii rylczaków oraz dwóch potencjalnych półwytworów liściaków. Istotny element stanowiły także czynności związane z obróbką krzemienia, choć, jak wykazano w toku analizy debitażu, zakres tych działań ograniczony był raczej do doraźnego pozyskiwania półsurowca od wcześniej przygotowanych rdzeni, wstępnie zaprawionych $\mathrm{w}$ innym miejscu, poza obszarem obozowiska. 

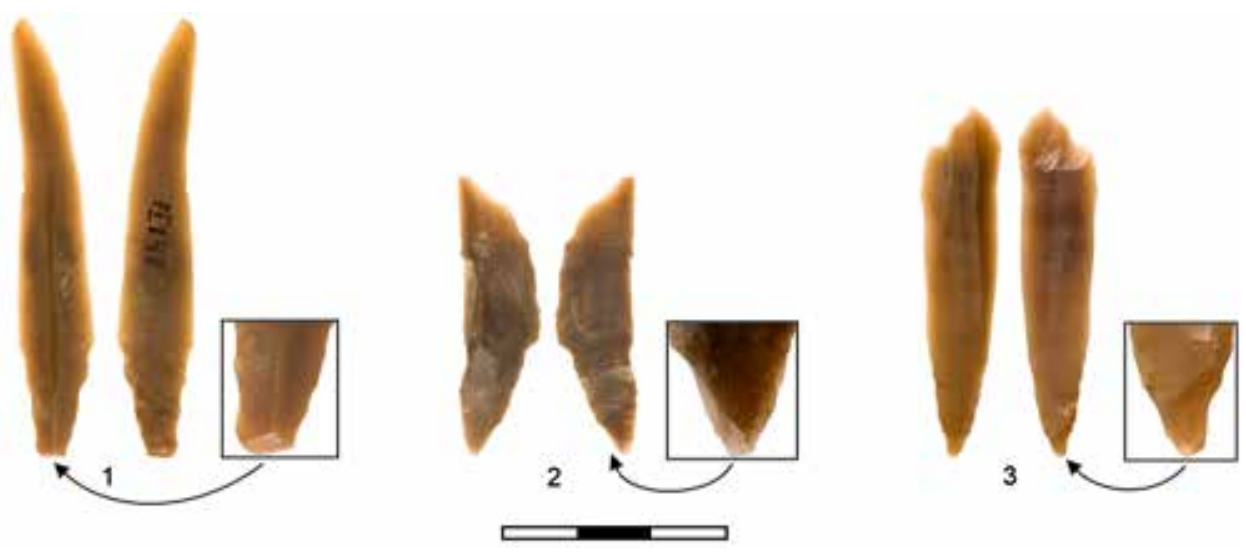

Ryc. 9. Przykłady liściaków ze specyficznymi śladami formowania trzonka (rys. M. Przeździecki)

Fig. 9. Sulejówek site 4. Examples of tanged points with specific traces of shank formation (drawing by M. Przeździecki)

\section{PODSUMOWANIE}

Przeprowadzona analiza wskazuje na zasadniczo homogeniczny charakter badanego zbioru zarówno w wymiarze surowcowym, technologicznym, jak i typologicznym. W procesie klasyfikacji kulturowo-chronologicznej inwentarza sulejowskiego podstawowe znaczenie mają dwa ostatnie argumenty, tj. zidentyfikowanie atrybutów metody i techniki łączonych z koncepcją obróbki „rdzenia mazowszańskiego” oraz obecność reprezentatywnej serii liściaków dwukątowych. Wymienione atrybuty bez większych wątpliwości pozwalają łączyć materiały odkryte na stanowisku z osadnictwem późnopaleolitycznej kultury świderskiej (Schild, 1975; Kozłowski, 1999). $\mathrm{Z}$ propozycją takiej klasyfikacji dobrze koreluje współwystępowanie drapaczy oraz rylców, które wraz z liściakami tworzą typowy (trójelementowy) zestaw, właściwy dla tej jednostki taksonomicznej. Obecność zachowanych fragmentarycznie, a w efekcie niepewnych identyfikacyjnie form nawiązujących do ostrzy typu Lyngby sensu largo należy postrzegać przez pryzmat nieudanych/niedokończonych półfabrykatów. Z kolei w przypadku okazu przypominającego liściaki Hintersee możemy mieć do czynienie z doraźnym działaniem (dostosowaniem) o charakterze funkcjonalnym lub technologicznym.

Postrzeganie tych pojedynczych elementów jako domieszki materiałów innych kultur należy zdecydowanie odrzucić, przede wszystkim z powodu wyraźnej spójności technologicznej zbioru, wyrażającej się zarówno w cechach debitażu, jak i narzędzi, czego dobrym przykładem jest tożsamy w przypadku ostrzy świderskich i ostrza typu Hintersee sposób formowania trzonka za pomocą zabiegu quasi-rylcowczego. Odrzucić należy także tezę sugerującą związek opisywanych materiałów z inwentarzami kultury wołkuszańskiej (Szymczak, 1995, s. 13, 14, 30-36) lub w bardziej 
ogólnym ujęciu z tzw. starszymi zespołami z liściakami, wg. propozycji R. Schilda (2020), które z racji na współwystępowanie liściaków różnych typów mogłyby być $\mathrm{w}$ tych rozważaniach brane pod uwagę. Taka interpretacja pozostaje w sprzeczności głównie z cechami wiórów oraz rdzenia, które znajdują ścisłe i liczne analogie w materiałach świderskich (Pyżewicz i in., 2019). Jednocześnie różnią się one wyraźnie od atrybutów debitażu wołkuszańskiego (Przeździecki, 2014, 2019). Ważnym argument w tej dyskusji z jednej strony potwierdzającym proponowaną przez autora klasyfikację kulturową analizowanego zbioru, z drugiej zaś wzmacniający tezę o jego odrębności od starszych zespołów z liściakami wydaje się kwestia preferencji surowcowych. Charakterystycznym atrybutem stanowisk świderskich z obszaru środkowego Mazowsza, znajdującym odzwierciedlenie także w zbiorze sulejowskim, jest wysoki udział krzemienia czekoladowego. Na niektórych z nich frekwencja zabytków z tego surowca osiąga ponad 90\%, zaś wytwory z kredowego narzutowca oraz pojedyncze znaleziska z surowca świeciechowskiego stanowią niewielką domieszkę. Taką strukturę obserwujemy m.in. w Całowaniu (Schild, 2014, s. 176), Świdrach Wielkich czy Grochalach (Schild, 1975, s. 316). Z odmienną sytuacją mamy do czynienie w przypadku - łączonego ze starszymi kulturami liściakowymi - inwentarza z poziomu V w Całowaniu (wykopy VIII, IX, XIII), gdzie zdecydowana większość wyrobów wykonana jest z krzemienia narzutowego (Schild, 1975, s. 277-279).

Jak już wcześniej wspomniano, propozycja kulturowo-chronologicznej klasyfikacji zbioru znajduje silne potwierdzenie w wymiarze technologicznym. Dotyczy to obecności charakterystycznych typów form wiórów i odłupków, ale także specyficznych atrybutów techno-morfologicznych. Głównymi cechami wyróżniającymi debitaż świderski od innych kultur kręgu z liściakami są regularność i wysoki stopień standaryzacji (rdzeni, wiórów, a nawet odłupków). Z kolei jednym z najważniejszych markerów wiórów świderskich są punktowe piętki ze śladami silnego przecierania (prawcowania) krawędzi, którym towarzyszą niewielkie słabo wyrażone sęczki. Z kolei w przypadku rdzeni za dystynktywne należy uznać występowanie dwóch naprzeciwległych wyraźnie wyodrębnionych pięt oraz intensywną zaprawę, zwłaszcza płaszczyzny tylnej przyjmującej postać tzw. grzebieniska (Dziewanowski, 2006; Przeździecki, 2006). Wszystkie te cechy zarejestrowane zostały w kontekście omawianych materiałów.

Przeprowadzona analiza surowcowa dostarcza także podstaw do formułowania ostrożnych uwag dotyczących mobilności paleolitycznych mieszkańców obozowiska, wskazując na dalekosiężną, a przy tym wielokierunkową sieć kontaktów (wymiany, migracji).

O ile relikty osadnictwa schyłkowopaleolitycznego na stanowisku 4 w Sulejówku dostarczają stosunkowo wielu danych na temat jego charakteru i intensywności, o tyle obecność pojedynczej formy o proweniencji mezolitycznej (półtylczaka typu Komornica) jest trudna w interpretacji. Ten ewidentnie „obcy” element, wyraźnie wyróżniający się na tle pozostałej części inwentarza, zarówno pod względem typologicznym, morfometrycznym (mikrolit), jak i użytego surowca (krzemień narzutowy), to najpewniej efekt krótkotrwałego pobytu na obszarze stanowiska przedstawicieli lud- 
ności kultury komornickiej. Fakt, że nie pozostawili oni po sobie innych świadectw, wskazuje nie tylko na epizodyczny charakter tej wizyty, ale także ograniczony zakres realizowanych w jej trakcie aktywności.

Należy podkreślić, że mimo szczegółowej analizy wiórów pod kątem cech charakterystycznych dla debitażu mezolitycznego, nota bene stosunkowo łatwych w identyfikacji, nie udało się takowych zarejestrować. Ewentualnie z dużą dozą ostrożności z osadnictwem holoceńskim na stanowisku 4 w Sulejówku można by łączyć - omawiany już wcześniej - zatępiec z krzemienia narzutowego.

Oczywiście nie można wykluczyć interpretacji, według której pierwotnie znacznie intensywniejsze pozostałości osadnictwa mezolitycznego zostały całkowicie zniszczone podczas prac budowlanych. Niemniej nawet przy założeniu, że potencjalnie materiały te zalegały w usuniętych przez spychacz wyższych poziomach, wydaje się mało prawdopodobne, aby przynajmniej pewna ich część nie przedostała się grawitacyjnie do poziomu z zabytkami schyłkowopaleolitycznymi.

\section{BIBLIOGRAFIA}

Andrefsky, W.

2005 Lithics. Macroscopic Approaches to Analysis. New York: Cambridge University Press.

Bodu, $\mathrm{P}$.

1996 Les chasseurs magdaleniens de Pincevent quelques aspects de leurs comportements. Lithic Technology, 21(1), 48-66.

Bogdański, J.

1990 Uwarunkowania geomorfologiczne. W: Z. Biernacki, J. Kazimierski, A. Wróblewski (red.), Środowisko przyrodnicze Warszawy (s. 90-97). Warszawa: Państwowe Wydawnictwo Naukowe.

Bradley, B. A., Giria, Y.

1996 Concepts of the Technological Analysis of Flaked Stone: A Case Study from the High Arctic. Lithic Technology, 21(1), 23-39.

Budziszewski, J.

2008 Stan badań nad występowaniem i pradziejową eksploatacją krzemieni czekoladowych. W: W. Borkowski, J. Libera, B. Sałacińska, S. Sałaciński (red.), Krzemień czekoladowy w pradziejach. Materiaty z konferencji w Orońsku, 08-10.10.2003 (s. 33-106). Warszawa - Lublin: Państwowe Muzeum Archeologiczne, Stowarzyszenie Naukowe Archeologów Polskich Oddział w Warszawie, Instytut Archeologii Uniwersytetu Marii Curie-Skłodowskiej w Lublinie.

Dziewanowski, $\mathrm{M}$.

2006 Flint assemblage Dręstwo 37. A preliminary analysis of predetermined Swiderian debitage. W: A. Wiśniewski, T. Płonka, J. M. Burdukiewicz (red.), The stone: technique and technology (s. 149-166). Wrocław: Uniwersytet Wrocławski, Instytut Archeologii, SKAM Stowarzyszenie Krzemieniarskie.

2011 On the classification of by-products of the reduction for blades - some aspects of technology in swiderian assemblages. Światowit (Nowa Seria, 9/B), 223-233.

Fischer, A.

1989 Hunting with Flint-Tipped Arrows: Result and Experiences from Practical Experiments. W: C. Bonsal (red.), The Mesolithic in Europe. Papers Presented at the Third Internation- 
al Symposium "The Mesolithic in Europe", Edinnburgh 1985. Edinburgh: Department of Archaeology, University of Edinburgh.

Kapera, H., Kruk, L., Hrybowicz, G., Kwecko, P., Tomassi-Morawiec, H.

2009 Objaśnienia do mapy geośrodowiskowej Polski. Arkusz Okuniew (525), 1:50 000. Warszawa: Państwowy Instytut Geologiczny, Państwowy Instytut Badawczy.

Kondracki, J.

2002 Geografia regionalna Polski. Warszawa: Wydawnictwo Naukowe PWN.

Korpak, J. (red.)

2020 Polska - regiony fizycznogeograficzne. 1:1 000 000. Kraków: Wydawnictwo Compass.

Kozłowski, S. K.

1999 Tanged Points Complex. W: S. K. Kozłowski, J. Gurba, L. Zaliznyak (red.), Tanged Points Cultures in Europe. Read at the international archaeological symposium, Lublin, September 13-16, 1993 (s. 28-55). Lublin: Wydawnictwo Uniwersytetu Marii Curie-Skłodowskiej.

Krukowski, S.

1939-1948 Paleolit. W: S. Krukowski, J. Kostrzewski, R. Jakimowicz (red.), Prehistoria ziem polskich, z. 1, Encyklopedia Polska PAU, t. 4 (s. 1-117). Kraków: PAU.

Libera, J., Zakościelna, A.

2002 Złoża krzemieni turońskich na obszarze przełomowego odcinka Wisły. W: B. Matraszek, S. Sałaciński (red.), Krzemień świeciechowski w pradziejach. Materiały z konferencji w Ryni 22-24.05.2000 (Studia nad Gospodarką Surowcami Krzemiennymi w Pradziejach, t. 4) (s. 93-109). Warszawa: Państwowe Muzeum Archeologiczne, Stowarzyszenie Naukowe Archeologów Polskich, Instytut Archeologii i Etnologii PAN.

Migal, W.

2006 On Various Methods of Lyngby Point Production. W: A. Wiśniewski, T. Płonka, J. M. Burdukiewicz (red.), The stone: technique and technology (s. 137-147). Wrocław: Uniwersytet Wrocławski, Instytut Archeologii, SKAM Stowarzyszenie Krzemieniarskie.

2007 On preferential points of the Final Paleolithic in Central European Lowland. W: M. Kobusiewicz, J. Kabacinski (red.), Studies in the Final Palaeolithic Settlement of the Great European Plain (s. 185-200). Poznań: Institute of Archaeology and Ethnology, Polish Academy of Sciences, Poznań Branch and Poznań Prehistoric Society.

Pelegrin, J.

2000 Les techniques de débitage laminaire au tardiglaciaire: critères de diagnose et quelques réflexions. W: T. Valentin, P. Bodu, M. Christensen (red.), L'europe centrale et septentrionale au tardiglaciaire. Confrontation des modèles régionaux de peuplement, Actes de la table-ronde de nemours, mai 1997, Mémoire du Musée de Préhistoire d'Île-de-France 7 (s. 73-86). Nemours: A.P.R.A.I.F.

Przeździecki, M.

2006 Reconstruction operating chain for selected blocks from „Jabłoń” trench in Wołkusz 5, as seen in refittings. W: A. Wiśniewski, T. Płonka, J. M. Burdukiewicz (red.), The stone: technique and technology (s. 127-135). Wrocław: Uniwersytet Wrocławski, Instytut Archeologii, SKAM Stowarzyszenie Krzemieniarskie.

2014 Krzemieniarstwo schytkowopaleolitycznej kultury wotkuszańskiej w świetle analizy materiałów ze stanowiska 3 w Wołkuszu, gm. Lipsk n/Biebrza, pow. augustowski, woj. podlaskie [maszynopis pracy doktorskiej].

2019 Studium technologiczne materiałów krzemiennych ze stanowiska Wołkusz 3 w północno-wschodniej Polsce. Koncepcja produkcji ostrzy preferencyjnych. Archeologia Polski, 64, 39-7.

Pyżewicz, K., Grużdź, W., Serwatka, K., Sobkowiak-Tabaka, I., Stefański, D.

2019 Swiderian lithic assemblages from Poland - some new observations and ideas. W: C. Montoya, J.-P. Fagnart, J.-L. Locht (red.), Préhistoire de l'Europe du Nord-Ouest: mobilité, climats et identités culturelles (s. 511-528). Paris: Société Préhistorique Française. 
Qintero, L. A., Wilke, P. J.

1995 Evolution and Economic Significance of Naviform Core-and-Blade Technology in the Southern Levant. Paleorient, 21(1), 17-33.

Sawicki, L.

1933-1936 Przemysł świderski I stanowiska wydmowego Świdry Wielkie I. Przegląd Archeologicz$n y, 5(1), 1-23$.

Schild, R.

1971 Lokalizacja prahistorycznych punktów eksploatacji krzemienia czekoladowego na północno-wschodnim obrzeżeniu Gór Świętokrzyskich. Folia Quaternaria, 39, 1-61.

1975 Późny paleolit. W: W. Chmielewski, W. Hensel (red.), Prahistoria Ziem Polskich, t. 1 (s. 159-338). Wrocław - Warszawa - Kraków - Gdańsk: Ossolineum.

2014 Calowanie. A final paleolithic and Early Mesolithic Site on an Island in the Ancient Vistula Channel. Warsaw: Polish Academy of Science.

Solon, J. i in.

2018 Physico-geographical mesoregions of Poland: verification and adjustment of boundaries on the basis of contemporary spatial data. Geographia Polonica, 91(2), 143-170. DOI: 10.7163/GPol.0115

Szymczak, K.

1995 Epoka kamienia Polski pótnocno-wschodniej na tle środkowoeuropejskim. Warszawa: Wydawnictwa Fundacji „Historia pro futuro”.

Taute, W.

1968 Die stielspitzen-gruppen im nördlichen Mitteleuropa: ein Beitrag zur Kennetnis der späten Altsteinzeit. Köln: Böhlau.

Wilke, P. J., Qintero, L. A.

1994 Naviform Core-and-Blade Technology: Assemblage Character as Determined by Replicative Experiments. W: H. G. K. Gebel, S. K. Kozłowski (red.), Neolithic Chipped Stone Industries of the Fertile Crescent. Proceedings of the First Workshop on PPN Chipped Lithic Industries, Studies in ancient Near eastern Production. Subsistence and environment (30-60). Berlin

Wąs, M.

2011 „Janisławickie” i „wstęgowe” koncepcje rdzeniowania wiórowego. Próba konfrontacji Technologicznej. Folia Archaeologica, 28, 5-21.

\section{SWIDERIAN CULTURE HUNTING CAMP AT THE SITE 4 IN SULEJÓWEK, MAZOVIAN VOIVODESHIP}

\section{Sum mary}

The objective of this paper is to present the results of analysis of flint artefacts recovered from excavations at site Sulejówek 4, Mazovian Voivodeship, in 2019 (fig. 1).

Due to the fact that before the excavation process the site was damaged to a considerable degree by removal of the overlying layer no. 1 (the level of humus and faintly marked illuvial level), all remarks concerning the stratigraphic and vertical location of the artefacts must be limited to the statement that they were dispersed in terms of the depth in the thill of a small dune with an underlying layer of quaternary clay - layer no. 3. The horizontal distribution of the objects is equally uncertain, although in this case, it is possible to distinguish two badly damaged but clearly identifiable concentrations I and II (fig. 2). 
593 flint artefacts were documented. Apart from two items made of Baltic erratic flint, as well as a fragment of a blade made of Świeciechów flint, the artefacts were made of chocolate flint. The specimens made of chocolate flint represent all techno-morphological categories associated with:

- the processing of cores (blades, flakes, chips from different phases of debitage),

- the process of production, use and repair of tools.

Three main categories of products (fig. 3) can be distinguished in the analysed material at the most general level:

- debitage products which include blades and bladelets -207 specimens, flakes -109 specimens, chips -176 specimens and a core - one specimen (fig. 4);

- modified products, including typological tools (retouched forms) - 19 specimens, together with characteristic refuse from their production or repair - six specimens, as well as the socalled functional tools - five specimens (fig. 6);

- damaged pieces - various types of non-debitage chunks and pieces, e.g., thermo- or cryogenic ones -70 specimens (fig. 3 ).

The analysis of the group of the debitage products above all draws attention to the consistency of its components in terms of technology. It is reflected both in the presence of specific product categories, e.g., two complementary types of blades, that is predetermining and predetermined forms, and in the set of morphometric attributes that they represent, e.g., double-platform blades with strongly prepared butts and marked lips.

Other important features of the analysed assemblage is the presence of debitage characteristic of almost exclusively advanced phases of processing and a high share of selected forms with a marginal percentage of defective specimens.

As far as the types of the retouched forms are concerned, we should note a clearly marked division within this group: elements of weapons - arrow heads (fig. 7: 1-7; fig. 9), which reflect the hunting activity, as well as tools of daily use, associated with a group of activities, the so-called household chores, end-scrapers (fig. 7: 8-11), traditionally connected with the processing of hides, burins (fig. 7: 12, fig. 8: 6) and retouched blades (fig. 8: 1-5), connected with the processing of animal carcasses.

The technological types and the range of tools suggest the attribution of this material to the settlement activity of the Late Palaeolithic Swiderian culture (Schild, 1975; Kozłowski, 1999).

A microlithic truncation of Komornica type (fig. 8: 4), which is a more recent Mesolithic component, is the only obviously foreign form in this inventory. It differs from the other specimens in terms of the raw material, typology and technology. 